\title{
Chapter 3 Intellectual biography of Latin American academic women
}

\section{Capítulo 3 Biografía intelectual de las académicas latinoamericanas}

ARTEAGA-CASTILlO, Belinda $\dagger^{* \prime}, \quad$ ALVARADO-SÁNCHEZ, Martina”, CASTAÑEDAMENDOZA, Edith"' and TORRES-ALEJO, Andrea"'"

'Instituto Iberoamericano de Historia de la Educación y Memoria Escolar (IIHEME), Mexico.

"Benemérita Escuela Normal Manuel Ávila Camacho, Zacatecas, Mexico.

"'Escuela Normal de Chalco, State of Mexico, Mexico.

"'Universidad Autónoma Metropolitana, Iztapalapa, Mexico.

ID $1^{\text {st }}$ Author: Belinda, Arteaga-Castillo / ORC ID: 0000-0002-8229-0042, CVU CONACYT ID: 236396

ID $1^{\text {st }}$ Co-author: Martina, Alvarado-Sánchez / ORC ID: 0000-0003-1739-095X, CVU CONACYT ID: 240448

ID $2^{\text {nd }}$ Co-author: Edith, Castañeda-Mendoza / ORC ID: 0000-0002-7371-2936, CVU CONACYT ID: 242657

ID $3^{\text {rd }}$ Co-author: Andrea, Torres-Alejo / ORC ID: 0000-0003-3940-8700, CVU CONACYT ID: 364510

DOI: $10.35429 / \mathrm{H} .2021 .10 .29 .52$

B. Arteaga, M. Alvarado, E. Castañeda and A. Torres

* barteaga@upn.mx

A. Marroquín, J. Olivares, D. Ventura, L. Cruz. (Coord.) CIERMMI Women in Science TX Humanities and Behavioral Sciences. Handbooks-@ECORFAN-México, Querétaro, 2021. 


\begin{abstract}
The text that we present here constitutes the progress of a collective investigation that emerged in the inter-institutional seminar on the history of women's education Aquelarre (Coven), named as a metaphor of the power of women and as a way to summon and describe the heterogeneous and vigorous group of academics that conform it, and who meet to debate, reflect and take action in the violent times in which we are living.

From our first meetings, it was clear that the reason that brought us together was the need to understand -more deeply- the academic and Mexican women that we are approaching in this paper. But, in which way can we determine the main characters of these narratives? In what manner can we approach them? How to explain the plots these women have weaved to become the text they wanted to become?

To apprehend these complex stories, we opted for a multidisciplinary perspective that combines history with gender perspective and intellectual biography. From there we tried to decipher the women summoned to our Coven. They are the Mexicans Luz Elena Galván (educational historian, author of multiple investigations and researcher trainer; we are focusing on her in this presentation), Belinda Arteaga and Marcela Santillán, as well as Peruvian Lucrecia Janqui. All of them willing to assert themselves to make their emotions, rational choices, alliances, proclamations and sedition acts visible. All of this with the intention of breaking apart, and emerging in the midst of silence, prohibition and obscurantism as victorious women who make their own way as they walk (as the poet once sung [reference to song]).
\end{abstract}

\title{
History of education, Academic, Women, Gender, Intellectual biography
}

\section{Resumen}

El texto que aquí damos a conocer, constituye el avance de una investigación colectiva que surgió en el seminario interinstitucional de historia de la educación de las mujeres Aquelarre, llamado así en parte como una metáfora del poder de las mujeres y, en parte, porque convoca y describe al heterogéneo y vigoroso grupo de académicas que lo integran y que se reúnen para dialogar, pensar y actuar en los violentos tiempos en que vivimos.

Desde nuestras primeras reuniones, tuvimos claro que lo que nos unía tenía que ver con la necesidad de comprender a las mujeres que estudian y que se desarrollan en los ámbitos académicos de nuestro país. Pero ¿Cómo identificar a las protagonistas de estas narrativas?, ¿Cómo acercarnos a ellas?, ¿Cómo dar cuenta de las tramas que construyeron para ser lo que decidieron ser?

Para aprehender estas historias de suyo complejas, optamos por una perspectiva multidisciplinaria que conjunta la historia con la perspectiva de género y la biografía intelectual. Desde ahí intentaremos descifrar a las mujeres convocadas a nuestro Aquelarre. Ellas son: las mexicanas Luz Elena Galván, Belinda Arteaga y Marcela Santillán, así como Lucrecia Janqui de Perú. Todas ellas dispuestas a sentarse a la mesa para visibilizar emociones, elecciones racionales, alianzas, proclamas y sediciones al conjuro de las cuales crearon alianzas, irrumpieron en medio del silencio, la prohibición y el obscurantismo y gozosas partieron para hacer camino al andar, como alguna vez cantó el poeta...

\section{Historia de la educación, Academia, Mujeres, Género, Biografías intelectuales}

\subsection{Introduction}

The history of women, in plural, was transformed in the second half of the twentieth century, enriched by works like Simone de Beauvoir's The Second Sex and by social movements pervaded by feminism in all its manifestations. Certainly, a breakpoint came with the awareness that gender was a social and historical construct, and that being a woman, beyond any anatomical signs (like having specific genitalia), was a more complex issue that involved symbolic and cultural structures. Women, as we know, live in patriarchal societies that are characterized by inequality, violence and exclusion. They coexist with -or rather live alongside- men, who are most of the time opposed to any change in this hierarchical order and to any alteration of the gender relations that make of them the Pater Familia, the owner, the one who expresses and decrees. 
It is against this status quo, whose history is complex and has long existed (but can be changed), that diverse feminisms raised questions trying to clarify these gender relations, along with their historicity and their possibility for transformation. One way to contribute to this, from our standpoint, was to make these women visible; women who, from the academia, chose to create crucial works and to build better, wiser and -with it- happier worlds.

These women had to struggle with the usual hostility of a social context in which they were not really accepted, and in which their academic work was constantly questioned. Today, the work of these warriors (for so they are) has gained visibility. Aquelarre's historians have summoned them to help us delineate those threads that allow us to reveal their unknown and enigmatic lives, all done from genderbased, historical and biographical perspectives.

With this objective in mind, we made choices. First, and this was the most difficult, our theoretical framework was based on a transdisciplinary conception. This conception was integrated by three aspects: a perspective focused on gender, the history of education -that takes from social and cultural historyand intellectual biography. These, put together, granted us a way to articulate the binary relationships, that are never simple nor direct, between subjectivity/objectivity, past/present, rationality/emotion, design/vital project. We were aware of the fact that disciplines like biography, and focal points like gender perspective, had to deal with academic prejudices that invalidated them and questioned their very grounds. Nonetheless, we accepted the challenge that comes with the stance we are taking in exchange for the possibility to navigate within symbolic universes that made possible for us to learn, thoroughly, about the life, achievements and struggles of the women that we are studying in this paper.

\subsection{Rise and fall of biography: between life and the pen}

François Dosse has studied the history, debates and methodologies of biographical writing. He has made clear that writing a life story is indeed difficult, but it is also "a privileged way to start reconstructing an age from its hopes and fears", making evident that individuality is present as well [in that age]: "writing a life story is still an unreachable deed, and yet, it keeps pushing the desire to narrate and comprehend it" (Dosse, 2017, p. 15).

In the last century and a half, history as a discipline fought to gain a reputable place in the social sciences. As it was achieving it, biography was also getting close to legitimacy through its links with literature, and its use of intuition, emotion and subjectivity as valid instruments in research.

The debate about biographical writing used to put the biographer in the place of the novelist, something that, according to the paradigms of that time, placed her/him away from the paradigm of a social scientist. This caused the biographer to be looked down on by historians, even though we can see the biographer is now placed in the centre of "the more innovative historiographical trends" (Pereira, 2008, p. 462).

But, regarding legitimacy, exactly what difficulties has biographical writing experienced? Despite the peak of biography as a discipline in United States, France, England and Mexico, "there is still some resistance in academia to tackle this genre because it keeps being considered an inferior form since it focuses on just one life, considering the context as mere background" (Bazant, 2018, paragraph 5).

Nowadays, the theoretical and methodological scope of biography covers the reconstruction of a particular life, as well as the study of the roles and contexts in which the biographer's story develops. In this sense, it tries to weave a bridge between history's more tangible sources (direct recorded data) and narrative (that implies an imaginative effort). Biography is thus a text that stands as both authentic and versatile:

... biography demands the use of all kinds of sources, [...] the study of one life inevitably leads to learning about other lives and other stories. Virginia Woolf, based on her own experience as biographer, aimed to merge the part of "truth in its hardest form" (solidity like granite) and the ethereal brightness of personality (intangibility like rainbow). Woolf [in her essay "The Art of Biography"] talks about the fact, or truth, which is able to evoke and engender the historical data. This data, next to the subject, is turned into something alive, unique and creative; the subject brings the fact to life, and not the other way around. Through someone's personal history, we can brighten the past in many ways. (Bazant, 2018, par. 7). 
Approaching life writing can be difficult. Since life's stories are elusive, "we need to have a panoramic and educated vision, and at the same time use intuition to detect the more elusive elements" (Bazant, 2018, par. 41). In this respect, through her own experience, Aurelia Valero presents at least three obstacles she has seen biography facing whenever this genre is evaluated from its basis.

The limits of narrating a private life: This relates with the idea of acquiring a critical view of the subject's life from "the back door", that is, looking at the events of her/his personal life. All of this for the sake of bringing out the subject's possible misconducts, overlapping these events with her/his work.

Trying to erase the subject: This approach proposes the removal of the biographed's feelings and personal experiences from the inherent value of the work; in here, the subjects are looked at through a lens of pure logic. So, to speak, the arguments should stand on their own, so they do not need anything more than its own coherence.

In this particular instance, the subject appears as a disembodied being who enunciates, articulating ideas that are completely dissociated from her/his ordinary life. This stance affirms that "the author's life is not relevant for her work, instead, what is important is the series of books that delineate her intellectual life, away from prosaic events" (Valero, 2013, 12m 30s). In this view, the value of experience, as well as the role of the author's personality in her own work, are questioned; the finite aspect of life is reduced in order to exacerbate the durability of the work.

- Life and its context are not the primal cause of a work: This stance presupposes that ideas do not come from interaction with other people, nor from shared thoughts. In this form of intellectual biography, the biographer has shown an overall disdain for aspects of everyday life, including family and objects.

This genre is born to counterbalance the extra limitation on privacy: "an attempt to norm the elements that, within that life, create meaning, and the elements that do not" (Valero, 2013, 14m 54s). In this regard, the work and its reception in public life is prioritized over the private aspects. This is done with the purpose of avoiding arguments where follies and failures existing in the author's life should not come to interfere with her/his intellectual output. Both life and thought are immeasurable; nothing should be said of the author, because knowledge, as an objective and universal paradigm, lies far away from the personal, domestic and private sphere.

Historians have attempted to mend this outlook on intellectual works by using the ability of intellectual biography to select any subject of study and emphasize the parts where the subject has dedicated to increase her/his knowledge. "Her/his context, experiences, objects and other subjects involved are never excluded from the narratives and contributions of intellectual works" (Valero, 2013). Following the line of Dosse, we can define intellectual biography as a "detailed study of the relationships between intellectual postulates and the trajectory of intellectual thought and praxis" (Gómez, 2021, p $80)$.

We can use such an outlook to write the intellectual biographies of these women and, with it, help counteract the incessant invalidation their research has been subjected to since it was first included as a professional and autonomous area of study. In this regard, Lourdes Alvarado has said that the critical view of historians tends to falter when it comes to the higher education of women: "except for occasional exceptions, they keep repeating this pattern in which certain assertions, always vague and ambiguous, are made; assertions that obliterate the very relevant - even if fewer-contributions that these women have made" (Alvarado, 2004, p. 13).

To draw closer the use of methodological hypotheses and current biographical perspectives in this paper, we started reviewing contemporary historiographical paradigms, as well as the history of women that has been proposed by the social historian Joan Scott. Because of her proximity with the historical narration of women, we reintroduce the paradigmatical Nouvelle Histoire (New History), a historiographical current started by Jacques Le Goff and Pierre Nora -belonging to the third generation of the Annales School that emerged in the 1970s. 
We chose the New History precisely because it recovers "new points of view" and "new objects". It is a history created as a response to "the traditional paradigm that focuses on the study of politics, religion and the state (Burke, 1996). Because of this, it paves the way for new research that includes relegated and vulnerable groups. This makes it relevant to our study, given that it provides the foundation for our histories of women.

The first half of the twentieth century saw the arrival of social history. This new discipline addressed subjects that had been previously discarded since they were considered objects that lacked history (such is the case of women). "Everything that was previously considered unchangeable, was now seen as a social construct that depended on variables that changed according to time and space" (Burke, 1996, p. 14).

In this research, we are recovering the social history that brings a multidisciplinary view to narrative and the narration of women's life stories. It retrieves, as an object of study, the construction of the idea of "feminine" in different social levels. As mentioned, one of social history's representatives, pertaining the study of women, is Joan Scott. It was with her that several questions started to emerge in this discipline. The uses, the ways they were enunciated, how they were implemented, justified and transformed over time, were all elements in the social and political life of women that gained relevance with her research (moreover about academic women). It was from these questions that they started noticing how these uses were being applied as a way to justify inequality, both at that time and throughout history. It is Joan Scott who insists that "human gender is in itself a question that can only be answered, bit by bit, through scientific research, made by scientists like historians" (Scott, 2009, p. 110).

The analysis of the intellectual biographies of women is often done reflecting on its use within a field in which the historian brings into play the epistemology of discipline, literature and human sciences. "Biography as a genre acquires this fundamental idea of bursting the absolutizing bubble and ending the distinction between a truly literary genre and a purely scientific dimension; since biography provokes hybridism and mixture, it also expresses the points of clash and collusion between literature and humanities" (Dosse, 2007, p. 24).

The limitations of the intellectual biography of women have often been a subject of debate between those who separate the life from the work of the authors, and those who see both as inevitably connected. "Intellectual biography is a way to break apart from established (crystalized) chronologies and the succession of isms that has characterized literary historiography. The latter ends up dehistorizing their own subject when they narrow the individual's sphere of activity. This is especially true for the study of women, since they have been first relegated, and then criticized when crossing to the public sphere.

That is why, in this research, we have decided to approach this genre from its link with the academic contributions made by women in the twenty-first century. Aurelia Valero has insisted that today, intellectual biography should not only recover the stories of distinguished and famous figures, likes renowned scientists and philosophers, along with their assertions and canonical work, but also pay attention to the events in their lives, connecting these with their intellectual production.

\subsection{A hidden legacy: approach to the intellectual biography of Latin American women in academia}

This investigation proposes that the study of intellectual biographies of academic women is still a subject largely to be explored. This can be seen in the state of knowledge of this genre and in its specificity. We analysed what, how and who has mentioned and published on this topic during the last decade. To gather this information, we checked the official States of Knowledge of the Consejo Mexicano de Investigación Educativa (COMIE, Mexican Council of Educational Research), especially the file Estados del conocimiento 2002-2011 that is confirmed by seventeen volumes (we used two of them). The documents we checked were Historia e historiografía de la educación en México Vol. 1 and Historiografía de la educación en México Vol. II (History and Historiography of Education in Mexico vol. I and II), both coordinated by María Esther Aguirre Lora. These two volumes were focused on women in academic and intellectual contexts. 
Following this line, we also reviewed some online dissertations (from bachelor and postgraduate's degrees) in the academic sphere, that included the Centro de Investigaciones y Estudios Superiores en Antropología Social or CIESAS (Center for Research and Higher Studies in Social Anthropology), the Centro de Investigación y Estudios Superiores CINVESTAV (Centre for Research and Advanced Studies), Universidad Nacional de Pedagogía (UPN, National University of Education Sciences), the Universidad Nacional Autónoma de México (UAM, Metropolitan Autonomous University) and Universidad Nacional Autónoma de México (UNAM, National Autonomous University of Mexico).

From this exploration we can conclude that biography has indeed been used to narrate several educational projects, as well as the academic and ordinary lives of its agents (academics). We found their life and work narrated, as a testament in paper, by their students, colleagues and some children. Some biographies also featured women in different periods in Mexico's history. We realized that, through biographical writing, we can relate everyday life, including events in community life and social occurrences from academia or the medical world; this has been used to bring the reader closer to that fantasy lived in scholarly contexts and in the life of others with whom the biographee's life is shared.

In the COMIE archive, we found that the Mexican states that have taken up biography are San Luis Potosí, Zacatecas, Michoacán and Guanajuato. In none of these there were registered narratives made by academic women and scientists. In the two volumes that were analysed, we could only find the biography of five women: Amalia Schacht, Francisca Ruiz Castillo, Elsa A.R., Pirita Escalante and Rita Cetina. In the case of Amalia Schacht, we read about her career and how she faced the same difficulties women in academia face when they have to excel in three areas: studies, work and children rearing. With Ruiz Castillo, the document we found was focused on her life and work (coining forgotten histories). We also found the multifaceted $\log$ book of Elsa A.R., the biography of Pirita Escalante as teacher and, lastly, Rita Cetina, devoted teacher dedicated to the education of girls in Yucatan.

Biography moves from the hidden plane in which these lives exist to the exterior (the public sphere). It focuses on fragments of the lives of women, whose story is difficult to unravel, to figure out and to make public. The biographical practice is in this way a complex exercise that can only let us glimpse the twists and turns of the plot; it cannot quite see the motives and the combination of elements produced by recovering a life story. It allows us to see only "the detective search for the author, who is concealed in her own text, her own strokes, signs and scenes (Arfuch, cited in Leñero, 2016, p. 323).

From the postgraduate papers reviewed, and the articles found in the CIESAS, CINVESTAV, UPN, UAM and UNAM, we have identified a contribution to this narrative on the lives of women, although these are stories that are many times dissociated from the fields of science and academia. In the CIESAS, we encountered ninety-one papers that used the biographical mode for their dissertation. We considered only the most recent ones; five of these were written between 2013 and 2014, and they focus on the lives of the women involved in politics and activism. In these documents, biography is also used to give an account of the importance of memory when recovering the histories of armed movements that have included women. These investigations are:

“Todas somos la semilla. Ser mujer en la política comunitaria de Guerrero: ideologías de género, participación política y seguridad" ("We're all the seed. Being a woman in the communitarian politics of Guerrero: gender ideologies, political involvement and security"), written by Ana Cecilia Arteaga.

"Experiencias de las asociaciones femeniles evangélicas en el Sureste de México, 1870-1960" ("Experience of Evangelical Female Associations in the Southeast of Mexico, 1870-1960"), that contains five biographies of protestant women and their inclusion in the associative phenomena in Mexico. 
"Revisión histórica de la guerrilla en Guadalajara: las fuerzas revolucionarias armadas del pueblo (1972-1982)". ("Historical Review of the Guerrilla in Guadalajara: The Revolutionary Armed Forces of the People, 1972-1982"). In this study, the author uses biography to recreate the revolutionary group of women that has been erased from canonical history. This specific section of the document is titled "Las FRAP y sus silencios en la comunidad de insurgencia" ("The FRAP and their silence in the insurgent community"). Here the author mentions the names of guerrilleras (guerrilla women) Montserrat Moreno Díaz and Dalia Gonzáles Hernández, whose nicknames were "Violeta" and "Paty", respectively. The investigation announces explicitly how difficult it is to retrieve anecdotes and different events for the historical analysis of particular lives: "they are the original starting point for the narrative reconstruction of the past, that is also redeemed, like a big piece of a puzzle that had been lost and it is found to take its proper place in history" (Zamora, 2014).

“Aquí la mujer se siente más responsable. Género y etnicidad Rarámuri en la Ciudad de Chihuahua. Entre relaciones de complementariedad y desigualdad" ("Here, women feel more responsible: Gender and ethnicity. Raramuri in the city of Chihuahua, between relations of inequity and complementarity"). This paper employs the biography of Feixa Carles (The Hourglass. Youth Cultures in Mexico), and articulates gender with ethnic inequality.

In the studies reviewed in the CIESAS, we could also find a document called "Mujeres transexuales y su reconocimiento legal en la Ciudad de México. Biografías y autobiografías de transexuales" ("Transexual Women and their legal acknowledgement in Mexico City. Biographies and Autobiographies of and by Transexual People"). In here, the author criticizes the use of biography to cover transexual women, questioning the reach that the perception of what is "feminine" has, along with the codes, symbols, behaviour and language used to limit all women.

As to the CINVESTAV, we reviewed in its archives an intellectual biography titled "Habitar el universo: el tema del trabajo en el pensamiento político de Simone Weil" ("To Inhabit the Universe: Work as a Theme in the Political Thought of Simone Weil"), written by Carmen Revilla. In this, the author recovers fragments from the vast academic work of Weil, who integrates her perception with philosophical problems in the twentieth century. In the same way, from the studies we reviewed in the CINVESTAV, we recovered the text by Carmen Revilla, who unearths fragments from the extensive biography of Simone Weil, along with the problems she faced in the twentieth century field of philosophy.

In UAM we found an intellectual biography: "Autobiografía ficcionalizada en la narrativa de María Luisa Puga" ("Fictionalized Autobiography in the Narrative of Maria Luisa Puga"). In this document, we can find the life of a woman through the "feminine autobiography", which uses memory, self-portrait, journal/diary, retrospection and autofiction. Finally, in UNAM, we reviewed documents that show the lives of women artists; such is the case of Nahui Olin, Mexican painter and poet. Other cases are the intellectual biographies, published in the form of magazine articles, about Brígida García Guzmán (a sociologist and demographer who worked as a professor and investigator in COLMEX) and Helena Antipoff (a renowned Brazilian educational psychologist).

\subsection{Aquelarre: an interinstitutional project for the recognition of women in science}

In the 1990s, the world as we knew was shaken by generalized crises in the global systems that predominated at the time. This created events that a decade before were unthinkable; some examples are the dissolution of the USSR, a global economic crisis, the reorganization of production systems and climate change. All these new realities could not be explained properly by the old social theories, as they became insufficient for this purpose. As a result, there was a -now called-paradigm crisis that would come to affect, particularly, the social sciences (Wallerstein, 1990).

This crisis was associated not only with theoretical problems, but with events and historical processes that called into question the basis of even the most solid hypotheses that had before been considered universal (in the nineteenth century sense of the word). In this manner, the centre of debate for Marxism, structuralism and positivism, just to mention some, orbited towards new perspectives that, instead, emphasized the aspects that were formerly discarded and considered unworthy of study; with this, the debate shed some light on objects that had been rarely studied and problematized. 
It is from such interpretations that we consider necessary to use some binary categories like identity/identities, social actors and totality/partiality, since they offer veins of meaning for the interpretation of social behaviour and for the encounter of humanity with its own subjectivity. The intervention of history and gender perspective as references and paradoxes contribute with elements that signal time (rhythm, cycles and duration), in addition to the hidden threads of collective development and the complex equation formed by the links between past and present, and the interrelation of subjects in patriarchal societies (usually Eurocentric and excluding).

Facing this ignominious data, social movements that are emerging compel us to build, from new, analytical and militant perspectives that go beyond simple explanations. These same perspectives open new paradigms and about new utopic views. In this sense, this text focuses on three key categories: genre/gender, history of women, and intellectual biography; all of which let us weave a framework in which we conceptualized the voice of the women presented in these biographies.

\subsection{Aquelarre and its complex formula: history, gender, genre and intellectual biographies of women}

In the last decades, biography has been employed to give an account of the life and work of women from all walks of life and in different areas: social, cultural and professional. We can attest to the fact that, when writing life, we can recover stories that are ordinary, communal, regional, and even those that extend beyond their geopolitical borders thanks to the common places they share with another culture.

However, there is still uncertainty regarding the way narration makes visible these lives and their work, especially when it comes to Mexican academic women. It is true that biography has been benefited by adopting a gender perspective, and by working with disciplines like sociology and history, among others; despite this, the contribution it makes tends to be less analysed because of the emphasis that has been put in their private life; an aspect that has been seen as merely emotional, intimate and purely subjective. That is why this investigation becomes relevant, given that its objective is to bring to light the intellectual progression of this group of academics. They largely contributed to Mexico's scientific development while being able to combine reason and sentiment, both pertaining to the inner life, which is basically a reflection of the public one. These women were able to navigate these symbolic universes, in which they developed their critical thinking, their interactions and their work (all equally valid).

We are not of the idea to take up their biographies from the dogmatic perspective that sees history as a master of life that attempts to catechize their subject and influence their formation; historical subjects should not be formed or led, they should not be forced to highlight certain features and identities, or to promote certain values that produce political and ideological opinions. What we are aiming at is to build these lives in a way that they generate questions, provoke criticism and contribute -as best as we can-to the acquisition of a historical consciousness regarding being women while being academics and being intellectuals, without giving up their utopic ideals and without having to die trying.

From the panoptic vision we have selected, we have come up with several questions to be attended: Which are the contexts and subjects that connected our biographed academics with the intellectual and academic projects that were most relevant in their lives? What are the most emblematic moments they, themselves, identify and relate when referring to their own narrative? What are these women appealing to and how they express it? What projects they were able to develop and in what specific moments? In which institutions, with whom, and what strategies they used for that purpose? From their own personal outlook, what are their own perceived contributions to academia?

From these questions, we infer our main goal: to recover the intellectual biographies of LatinAmerican women and learn, through them, the many ways, strategies, alliances and dissolutions that they lived and faced. All of these served as practice for them, to be able to develop the academic projects that marked their lives and the field in which they worked.

Here we present our specific objectives:

Explaining the context and subjective conditions that brought our biographees to the intellectual and academic projects that were defining for them and the field to which they contributed. 
To locate the emblematic moments that these women have identified in their own life's narratives.

To pick up their main undertakings and place them in the context in which they lived.

To observe, from their own point of view (as much as possible), and in detail, their contributions to their time and society.

\subsection{From the History of Women to the Historical Analysis integrating a Gender Perspective}

One of the most important movements back then (in the 1970s) was the French New History. This was a school of thought that involved the opening of history to other disciplines like geography and economy. This created a transdisciplinary exchange that allowed the explanation of historical processes from new perspectives. Such perspectives enabled the comprehension of the very complex phenomena that human beings were witnessing (whether in incredulity or horror).

The broad opening this French school created provided a niche for the presence and voice of a wide range of people; after this, it was not only heroes that appeared on histories, but men and women on the street, both just and impious, sane or mad (as they were categorized). Since then, history has fought many battles and, as a result, a promissory future is foreseen. One of the many benefits gained from these battles is, no doubt, the history of women and gender that started to be developed towards the middle of the last century.

It is necessary to point at the fact that there are no exact dates for the birth of this specialization in the discipline of history, but there seems to be an implied agreement upon two options. The first one indicates that the history of women emerges as a proposal connected to militant feminism, while the second one indicates that Simone de Beauvoir's The Second Sex started a new age in the debate about women and their stories in patriarchal societies that are marked by violence, exclusion and inequities. In the following decades, the growing number of studies on women's lives cleared the way for institutional spaces; from this on, there were new spaces inside centres of investigations, like universities, destined to this new type of research. Joan Scott (1991) talks about this:

In one of the conventional explanations upon this subject, feminist politics appears as the starting point... These explanations place the point of origin in the $70 \mathrm{~s}$, when feminist activists build a history that gave proof of the activity of women, explanations of their oppression and a motive for their actions... In the middle of this decade, the history of women widened its field of activity (through inquiries into their experiences) by documenting all the possible aspects in women's lives, what in turn propelled its own development.

In this sense, the history of women meant, from the beginning, a consistent effort to resignify their participation in the past and present of humanity, so as to recover their presence wherever their tracks had been blurred or erased. We can tell that this exclusion was deliberate, since anyone who literally-writes history, finds women who often contend, reclaim, debate, seduce, act, beg, but never give up. Such women promote or oppose to change, all from a diverse standpoint; they also construct their own identities from collectives or their own particularity; they assume principles, build up agendas, form alliances, stage brakeage, go forward or backward, but they are always there, on stage, being part of the scene.

To consider their presence, voices, and representations imply a theoretical challenge. It was about elucidating between writing a complementary or a parallel story, as Virginia Woolf suggested when she asked [in A Room of One's Own]: "why should they not add a supplement to history?... so that women might figure there without impropriety? (Wolf cited by Scott, 1991, p.70).

They could either add this supplement or elaborate one more of the serial braudelian stories (after Fernand Braudel) that, as a worrisome Lola Luna denounced once: "It's significant from a theoretical perspective that in the congress' tables... dedicated to the state of feminist methodology and historiography, was placed as an adjacent of cultural history. This gave way to a very specific question from the masculine side as to the history of women is sectorial..." (Luna, 1994, p. 21). 
They could also choose a third option: to write the history of women and men in relation with the general context of human history. This last alternative (that would prevail over the others) involved a critical reading of the epistemological assumptions in which traditional history (androcentric) rested, as well as the deep questioning of pretensions of totality, universality and sufficiency, according to Scott:

The history of women really entails the modification of history itself, because that it looks into the way in which this word came to be established... It should critique the relative priority given to the history of men over the history of women, exposing thus the implied hierarchy in nearly all historical accounts. What is more important, it raises questions about the integrity and blatancy of the usual subject of history: the universal man. (Scott, 1991, p. 72)

This new reading had many consequences. The first was the construction of a new and innovative gaze that took into account the experiences, discourses and practices of women that existed in a complex reality. It was in this same reality that diversity, interrelations and contradictions were practically inevitable.

That also implied the elaboration of categories that allowed historians to work with this object of study from its own specificities, and still be able to acknowledge that women interact in social and cultural contexts that are troubled by power relations in which men tend to have predominance, and in which both poles represent heterogeneous groups whose identities -like non stable equilibrium- are not fixed nor invariable. In this manner, the stages and sources, questions and hypotheses, required problematization in order to be capable of answering multiple challenges that comes with every creative effort. As Scott points when citing Gordon, Buhle and Shrom, it was about:

The inclusion of women that necessarily entailed the redefinition and extension of traditional notion of historic significance, in a way that covers both the personal and subjective experience, as well as the public and political ones... A methodology like this implies not only a new history of women but also a new general history... (Scott, 1990, p. 25)

Already in the 1990s, feminism had discarded the idea that the history of women was a serialized narrative that implied isolation of the protagonists from the social context inhabited, initially, by men and women alike. Contrarily, what predominated was the rewriting of history making these women visible, rescuing their voices, gazes and actions. But it would be necessary to introduce gender as a category to explain the connections, conflicts and interactions between human beings that are differentiated, not only by their sex, but by symbolic content and the identities that have been imposed/assign socially, historically and culturally to humans in general.

Following this logic, we can affirm that gender transcends the assumed presumption in which the body (physiology) determines our social role:

Gender can be used to designate social relations between the sexes. Its explicit uses reject any biological explanation ... Instead, gender denotes cultural constructions, a complete social [and historical] creation of ideas about roles and characteristics that are appropriate for women and men. Gender is, according to this definition, a social category imposed upon any sexuated body. (Scott, 1990, p. 28)

\section{Regarding this, Tinat (in Berger, 2015) remarks:}

Gender studies could be defined as the combination of researches that study women and men, the feminine and masculine, and everything that is displayed in between these two poles.

Even when the first stage of gender studies focused on deconstructing essentialist and biologicist paradigms of the sexes, other stages that came afterwards considered the concept of gender from a more relational characteristic. It was hence focused on power struggles and hierarchies. Throughout time, this conception has had more usage in the intersection with other categories like social class and ethnicity, that predominated social sciences.

In this way, we can assert that gender is not defined by bodies as unique, essential and ahistorical entities, but on the contrary, it is built culturally. Therefore, this is a territory delimitated by symbolic marks whose content is closely linked to power and subversion. Casali writes about this in (2020): 
What's true is that the sole fact of transgressing norms and delimitations (like the constructed idea idea of sex and gender) reflects the ability to recognize the cultural dimension of our gaze upon the world. No matter how much we as subjects try to construct a coherent narrative of our lives, imposed gender always reminds us that such a construction is arbitrary, polysemic and dependent on several factors; at the end none of this is written in stone.

And, definitely, the features that make us human vary socially, from culture to culture. Gender, as a category, admits several definitions that, depending on the emphasis and methodology given by every discipline, can have different resolutions. In this sense, history, from a gender perspective, is a discipline of inclusion. Beyond constraining itself with simple descriptions, it expands on the different depths of historical processes, along with the multiple and complex threads that are generated, and the presence and action of men and women who, with their voices, views, silences and struggles have constructed our social reality.

\subsection{Biography as a historiographical genre}

In the nineteenth century, biography was not a genre taken up by historians with a positivist mindset, and neither by those who, from a Marxist and structuralist point of view, were embarking in the field of history. The main objections these frameworks had on biography were related to their rejection of subjectivity and their attachment to objectivism, the latter validating only certain analytical processes that followed restricted established guidelines about social behaviour. From that perspective, they came up with explanations that readily denied the validity of all narrative that was even remotely linked to subjectivity and individualism.

In the twentieth century, with the emergence of the Annales school of thought (around 1929), there was a change in the perception of history; it started to be considered a discipline founded in the investigation of primary sources that had to be interpreted through theory; it required a rigorous analysis by historians. These historians operated collectively from a view that included multidisciplinary perspectives that were interacting and dialoguing among continuously with each other.

The Annales historians not only built alternative theoretical paradigms that made possible the opening of traditional history, but they also turned their eyes towards new objects of study in which subjects, who had been previously marginated, forgotten and invisibilized by a previous historiography centred on power, were suddenly the centre of new investigations. These new actors (children, women, teachers, mentally ill and dispossessed, among others) would take a central place and make their voices heard.

Sooner than later, biography would transit to academia too (not excluding frictions), leaving behind the heretical and spurious place into which it had been forced. It went from that academic condemnation to climb to the -now well known- Biographical turn (in 1990) that brought:

Apart from the exponential growth in the number of biographies, a practice that included self-reflection on biography as a genre and as an instrument of knowledge. In the same way, the theoretical debate on the epicentre of biography in social studies (Pinna, G, 2013, pp. 189 -190).

The genre of biography, already placed in a safer/secured position within academia, showed the multiple possibilities offered by the narrative that recovers the plots that connect sociohistorical and cultural contexts (the age/time according to Hobsbawm) with the actor's subjectivity (those whose lives are being studied). It focused on the multiplicity of identities intertwined in human life, on the spaces of intimacy and on public expressions; it also put into focus what is said, what is silenced, the unknown with the known and, at the end, like Marc Bloch said -very accurately- the profoundly human side of the object of history.

In this scenario, it is not by chance, nor unexpected, the encounter with a perspective based on gender, since it comes with a cosmovision and a conscious choice of signs (clues) to understand and live inside the world (as part of it). It is in this way that biography is closely linked with the histories of women and gender. Standing in that field/genre it becomes possible to summon, name and make visible these protagonists, as they take the floor to enunciate their questions, concerns, desires, emotions and potentialities/latent qualities. 
In consequence, it justifies the investigative efforts that precede this paper and that have allowed us to make clear their career paths joint with their life stories as Latin American women. We are thus able to account for their struggles, achievements and failures with a level of analysis that, quoting Johan Huizinga, confronts us with history in all its complexity.

By taking up biography, we do not intend to: "find its pathologies or neurosis but trying to find the threads that unite and motivate a human being to act, feel and behave in a certain way" (Bazant, 2018, p. 58). In sum, this investigation is about locating temporally some events in a woman's life and explain them through the history of gender, which not only focuses on sexuality but on marks like ethnic origin, social class, religion and political ideology. It also focuses on how these marks influence her choices, actions and both intellectual and academic priorities.

In light of this, we are not trying to identify in which way these women have played their cards so to speak - in a patriarchal society that is hierarchized, excluding and authoritarian as the Mexican one, but to define their projects and how they developed them even when having a clear disadvantage. The voices we are trying to recover through this investigation show us that, in many cases, women have been subjected to explanations that obliterate their circumstances (or even themselves), and it is our aim to show how, using a gender perspective, we can open spaces for their open involvement and active presence in spheres that had been traditionally closed to them, like work, academia and even the street.

We considered, in historical time, the medium-term conjunctures. This mainly because it allows for the historical reconstruction of the lives of these women, given its ability to describe different processes in periods of decades when profound cultural changes occur. By reading history through this lens we have been able to resume contemporary debates focused on gender, that tend to problematize not only the time in which these women lived, but also their world view and their practice.

Besides, seeing this dichotomy as a metaphor, we can point at the fact that the possible resolutions regarding identity that we women face are played within an essentialism of what is feminine and the relativism that gives validity to all and none; this last negates limiting structures like class, ethnicity, native language, religion and sexual orientation. As Lazreg points out (1990), the recognition of differences must include categories like class, race, religion, colour, etc. Acknowledgement cannot transform differences into divisions (differences enrich rather than set apart).

Another risk that this identification generates is the potential reduction in the ability to understand us (women) as a collective that is likewise joint by bonds and similitudes that place us in the same front. In this, there is a contradiction in the centre of anthropological practice. On the one hand, it attempts to understand, appreciate and interpret the cultural particularities in its own terms, when in this objective the ethnographic case studies have been fundamental. On the other hand, generalization as a problem, when the discovery of similitudes above diversity has led it to develop transcultural explanations ... (Sacks, 1989).

That said, the visibility of these symbolic connections between gender and other identity traces deserves our attention. Because of that, it is true that / In that sense, another element that is worth mentioning here is the use of binary dichotomies that have been used to classify women in a lower level. These are the opposites of private and public, body and representation, rationality and affectivity, among others. As such, they have been used to reproduce and legitimize dominance, not only in gender relations, but also involving ethnic discrimination and class exploitation. In sum, this investigation is about unravelling the complex thread of power networks that are generated and developed within patriarchal systems, societies and institutions; structures that are, in consequence, colonialist and capitalist too, since they are rooted in the same principles.

It is in this manner that we formulate the consideration of intersubjectivity as an alternative use to include that otherness, thus avoiding objectification and victimization of the other. In these stories we can verify a tendency of feminisms to blur the established borders of nations to get to a global-and in some way internationalist- perspectives that signal at the idea of gender identity been overpowering national identity. 
In the complex equations risen from theory to explain changes and permanence, and which have marked the struggle endured by women, it becomes necessary to give an account of the progress towards diversity, multiculturalism and inclusion that we are seeing today. This inclusion is articulated in ethnic and social class elements that, currently, are heading towards a holistic reading of the distinct identities that are expressed by different groups of women.

\subsection{Luz Elena Galván y Lafarga and her legacy in the history of education in Mexico}

The history of education in Mexico is a field of study that has grown over time. It focuses on educational processes and the different ways in which they develop. This focus has promoted a series of analyses and considerations that have enriched its own historiography.

Education can be seen as a historical process, that is, it is modified according to time and space (temporal and geographical loci). We can distinguish two of its objectives: on the one hand, it can provide knowledge and skills that will grant individuals the ability to cope and grow in their respective contexts. On the other, it can transmit the cultural elements pertaining their own society, what in turn will give them the opportunity to share a common identity and to feel they belong in a specific community or social group.

Historiographical contributions have opened a wide range of options for interpretation and comprehension of the state of education in Mexico. Several objects of study have been incorporated in these investigations and, at the same time, researchers have searched for new sources of information. As a result, the history of education has had notorious advances both nationally and internationally.

According to the theoretical and methodological lines followed by the historiography of education in Mexico, we can see three main foci in research that have shaped the analysis and conclusions on the educational processes of the past: social, cultural and regional history. One aspect that is important to note here is the fact that each one of these elements lacks a direct link with the other. Today, Mexican historiography considers the history of education -given its progress- as a specialized branch of history and gives an account of the relationships that can be developed between diverse methodologies of investigation (inquiry and analysis).

Presently, in Mexico, a network of researchers focused on our educational past has come together. This community of historians has been building the foundation of our current historiography on education. As we mentioned before, they have investigated diverse objects of study like women education, teaching, infancy, school culture, life in the school and regional history. This diversity has been approached thanks to their interdisciplinary effort, given that they have been able to use more theoretical and methodological instruments to widen the possibility of an accurate historical reconstruction to explain the processes they analyse. In short, the history of education in Mexico has become a dynamic field, in which the inquiries in public and private archives make of this area of study a very fertile one for future investigations.

Luz Elena Galván y Lafarga (1949-2019) worked in this scientific community; she was a prominent investigator whose contributions to the history of education are remarkable. Her relevance to the field can be seen in the fact that many of the topics taken up today were brought up by her. She coordinated and took part in the organization and publication of several works that, nowadays, have become almost mandatory reference books for all of us who develop an interest in the history of education in Mexico.

Because of this, we are going to have a first look into the reconstruction of Luz Elena Galván's intellectual biography. The purpose of this is to make an initial approach to her formative years and her beginnings as an education historian, and to cover later her most relevant works. 


\subsection{Mexico in the 1970s and 1980s: a complicated context}

Before we embark on this voyage/before we start reviewing the biography of Luz Elena Galván, it is important to describe Mexico in the seventies and eighties, since this was the period in which she started her academic career. Operating under the premise that all human beings are historical subjects, meaning a product of serialized events, we are implying that the political, economic, social and cultural contexts shape their ideas, stances and actions, as said by Eric Hobsbawm (2003). We know that intellectual biography allows the biographer (historian) to get close to the biographed by means of an exercise that connects the subject's inferred thought with their professional practice (their production, so to speak). We can reconstruct the path made by the hard work that such a person took and do it under the assumption that a life is complex and endless, and that is why it can always allow for new interpretations, according to the problematic approach, even with the same known sources (Gómez, 2021, p. 80).

In this regard, we need to contextualize temporally the professional practice of our biographed. The period we are going to refer the most in this text is the administrations of Luis Echeverría Álvarez (1970-1976) and José López Portillo (1976-1982). Some of the most relevant aspects -politically, economically but also socially- are related to education.

The beginning of the seventies in Mexico marked also the beginning of a new administration (a six-year term), whereas Luis Echeverría had been elected President. His six-year term begun immediately in the middle of social upheaval that had been increased by the killing of students in 1968 (after the student movements); this unrest was "particularly rooted in groups of intellectuals, in universities and leftist dissidents" (Delgado, 2008, p. 440). Economically, he presented a reform to repair the issues that had been generated by the past administration with the so called "desarrollo estabilizador" (stabilizing development), implemented from 1954-1970; this economical model consisted in government intervention to maintain the economy free from inflation and devaluation. This model allowed for the country to be industrialized, but only created wealth for the people who owned those industries, subsequently increasing poverty and social inequity. The decision to intervene in economical politics was grounded in a nationalist discourse that discarded foreign interests.

In the field of education, there were new institutions created, a direct consequence of population growth. In Mexico City, public education schools in preparatory and higher levels were having a difficult time, since the number of students apt to enter these levels had grown beyond their level of accommodation. Universities like UNAM and IPN did not have the capacity to integrate these new students. In consequence, there were new institutions founded: Colegio de Ciencias y Humanidades (CCH, Sciences and Humanities College) in 1971, Colegio de Bachilleres (secondary school graduates) in 1973 and Universidad Autónoma Metropolitana (UAM, Metropolitan Autonomous University) in 1974. Private institutions also created new places for the groeing population; according to the Asociación Nacional de Universidades e Instituciones de Educación Superior (ANUIES, National Association of Universities and Institutions of Higher Education), between 1970 and 1980 the number of students attending these tripled (ANUIES, s/r). An example of this is the Universidad Iberoamericana (IberoAmerican University).

Regarding research, there were policies promoted aimed at creating "pertinent infrastructure in investigation and technological advancements", particularly with the creation of Consejo Nacional de Ciencia y Tecnología (CONACyT, National Council for Science and Technology), that would come to replace the Instituto Nacional de Investigaciones Científicas (INIC): "From the seventies [...] there is a consistent effort in the reformulation of policies that would create the framework for scientific and technological development through institutions created specifically for that purpose" (Canales, 2007, p. 15). In this way, CONACyT was conceived as the institutional foundation in which future academic research would be built -through its support.

Despite this effort, Echeverria's administration did not end in the best way given the failed economic situation: 
... it was difficult convincing the private sector to increase their investment [...], the last year of that administration was characterized by the dollarization of the economy, speculative practices against the Mexican peso, generalized capital flight, restrictive policies and stagnant economy [...] in an attempt to maintain the value of the currency through its exchange rate at any cost, the public sector was incessantly falling into debt (both in short and long term). (Delgado, 2008, p. 452)

In the next administration (López Portillo's), the government set a series of public policies to reduce social disparity: Alianza para la Producción de 1976 (Alliance for the Production of 1976), the Coordinación General del Plan Nacional de Zonas Deprimidas y Grupos Marginados (COPLAMAR, General Coordination for the National Plan of Depressed Areas and Marginalized Groups) de 1977 y el Plan global de desarrollo en 1980 (Global Plan for Development). In the education sector it was included a budget for the creation of the Universidad Pedagógica Nacional (UPN, National University of Pedagogy) in August 1978. However, it should be pointed out that Mexico was going through a heavy financial crisis that accelerated towards 1982.

In spite of this, they kept creating policies to continue promoting investigation. At the beginning of the eighties, it was first discussed the creation of the SNI, National System of Researchers (Sistema Nacional de Investigadores). With this institution, they were hoping to create awareness as to the relevance in the formation of researchers; they were also trying "to increase the income of scientists without having a general increase of minimum wages, especially after the devaluation that the country had been through a couple of years before" (Canales, 2007, p. 98).

The context described (even if very syntactically) gives a first glimpse into the world in which Luz Elene Galván started developing her career. She accomplished many things in her life, becoming an eminent figure in the academic and research fields in humanities; moreover, she achieved this in a time when institutions that were meant to advocate for this were just being founded.

\subsection{Luz Elena Galván's approach to history and the history of education}

The history of education, just like many other histories, belongs to the past; that past which, from one way or the other, we carry within us, both as a memory and as an inherent part of us.

Luz Elena Galván

Luz Elena Galván y Lafarga, "Luce" as she was called affectionately, was born in Mexico City on January 22nd, 1949. She was an exceptional human being: an excellent academic and researcher, and always kind and polite to others. Colleagues and students alike speak well of her, stating the warm treatment they received from her and how this created many lasting relationships both with friends and co-workers.

From a very young age, she became interested in history. This interest had three relevant moments in its development. The first one happened in her childhood and adolescence (up until preparatory school); the second one during a trip abroad (to England), and the third one came to be when she was already in academia, by means of the interaction she had with eminent researchers: Enrique Florescano (1937-) and Guillermo de la Peña (1943-). In the following paragraphs we explain a little further these three stages.

Her first contact with this discipline occurred when she was a child. As a little girl, as she herself used to relate, one of her father's sisters had a liking for reading, especially history books. In the evenings little Luz Elena liked to go to her aunt's house to hear her reciting from them:

I had an aunt, my father's sister, that had worked as a secretary. She loved history, my aunt Clementina, and in the evening, she used to read to me history books, talking about Lucas Alamán and the history of Mexico. Then for me, well, it was like having adventures; as soon as I finished my homework I used to run to her house. There lived my grandma with my aunts, and none of them were married; a family of single women that lived just around the corner. Then I ran to their house and my aunt was already waiting for me to read me, and those were my happy evenings, with her reading pieces of history to me. (Historia Abierta, 2014, $3 \mathrm{~m} \mathrm{34s).}$ 
As years went by, Luz Elena Galván continued her studies; she reached preparatory school, which she studied in a private institute founded in 1903 by Marie Flavie Arnaud, from the Sisters of San José de Lyon, a Catholic order "whose dedicated labour was also the educational one". (Torres, 1993). During this period, Luz Elena Galván had two professors that endorsed even more her interest in the past: Norma de los Ríos and Cecilia Greaves. At the time, Galván had not considered a career in history but, undoubtedly, through her own interest and the meticulous teaching of her professors, the seed she had been given by her aunt sprouted and blossomed, as she herself said: "The way in which they taught us both universal history and the history of Mexico was very exciting" (Galván, 2014, p. 45). It should be noted that even in this point, Luz Elena had shown a keen interest in human sciences.

By the year 1967, she had finished her preparatory studies and had the opportunity to travel to Europe, specifically England. She stayed there for three years. It was an experience that would change her life; in her own words: "the world opened to me" (Historia Abierta, 2014, 3m 09s). What she lived there changed her perspective, allowing her to see a world that laid out the possibility of professional improvement for women. We must remember that, in addition to this, coming into contact with people from different parts of the world (and their respective cultures) who showed interest in the history of Mexico, especially the prehispanic period and the Museo Nacional de Antropología e Historia (National Anthropology and History Museum, opened in 1964), she became aware of her lack of knowledge regarding her own collective past: "to top it all, I was a Mexican who did not know my own history" (Historia Abierta, 2014, 3m 26s). From this moment on, she understood her distance with the past, a past she had learned to love but had not delved into it enough, and she was determined to change that and to make it her life's work.

She returned to Mexico in 1970 and acted on her resolution; she wanted professional growth, so she signed up to high education courses - event that we are going to see further in this text - and became a tourist guide in the aforementioned museum. Her skill in English was key in this development; she showed to be so good in this job that started to doubt which career should she pursue:

It was then that I started to discover what history and anthropology meant. Teachers like Eduardo Matos and Román Piña Chan, among many others, taught us the richness inhabiting that museum; that created doubt in me as to which path should I take: anthropology or history. (Galván, 2014, p. 45)

Finally, she chose the second option:

... the embarrassment for knowing next to nothing about my own history and nothing about the museum itself. That is why, when I returned to Mexico in the seventies, I signed up to the Universidad Iberoamericana and enrolled in a history major; the UNAM was still very turbulent due to the student movements -and their killing- in the 68'. It had closed many majors. The discipline of history was in the college of Philosophy and Letters, and it was the more stirred; teachers' attendance was rare, they skipped class whenever they wanted and I did not like that, so I came to the Iberoamericana, my alma mater. (Historia Abierta, 2014, 5m $16 s)$.

The days when she was not giving guided tours, she used to go to the library of the museum and study or do homework. In this academic context, Luz Elena interacted with historians who were already well known in the academic and intellectual world; this was an aspect in her life that widened her view. As she acquired more experience in here, both academic and at work, she assimilated this experience into her learning. Even before becoming a well-known figure in the field of historical investigation, she seemed to stand between anthropology and history as a mediator. She was more inclined towards history, as she herself stated, but even with that preference, anthropology was inevitably present in her personal life and in her approach to her work; by tossing in anthropology's overarching capacity in her historical investigations, she was effectively trying to understand the past through the present. In this fashion, Galván achieved an interdisciplinary equilibrium that would reflect upon her researches and all her historiographical contributions. To understand more deeply Luz Elena Galván's journey and the impression her trajectory made, we need to go back to her formative years in college. In 1970 she was admitted in the Iberoamerican University (former University Cultural Centre), as a history major. The university was private - and catholic - and had been founded, in 1943, by the Jesuit priest Enrique Torroella (1901-1984). This educational project was supported by the dean of UNAM, Dr. Rodulfo Brito Foucher (1899-1970). According to María Teresa Matabuena, Jesuits had an interest for higher education and they managed to establish this institution with a clear purpose: 
... that, bit by bit, they continue to add to the major of philosophy more disciplines like history, social sciences, journalism, pedagogy and STEM sciences. Thus, in March 1943, they opened the Centro Cultural Universitario (University Cultural Centre), whose aim was providing a college education with a propensity to include a humanist and philosophical vies, given that, for them, these perspectives were in compliance with Christian thought and the principles of the Society of Jesus. (Matabuena, 2018, p. 27)

Luz Elena Galván, as previously mentioned, chose history as her career, not only as General History, but specializing in education. This focus led her to write a dissertation on the historical figure of José Vasconcelos and the founding of the Secretaría de Educación Pública (Secretariat of Public Education) in 1921. In her last year in college, she had the opportunity to enter the world of research through her job and newly created connections (the network she built in academia). In 1973, Enrique Florescano had founded the Seminar on the History of Education in the Department of Historical Investigation in the INAH; a seminar of which she would eventually become part. Her studies and her involvement in a variety of academic practices laid the foundation of her fruitful career as historian. It was in that space that she found and fell in love with research; as she recalls, in academia she learnt how to investigate, to find the right sources, how to register and annotate a document (a book or any text) and even how to redact any paper (whether reports, articles, or even chapters) (Galván, 2014, p. 45).

Shortly after, this seminar changed its management and Guillermo de la Peña Topete took on the position of director. He had been formed in sociology and anthropology and had studied in the Iberoamerican University too -just like Galván-, later earning a doctorate in the University of Manchester (England). When De la Peña took office as the director of the seminar on the history of education, he was already a professor and investigator in the Centro de Investigaciones Superiores del INAH (CIS-INAH, Centre for Higher Education Research), where he was part of the program of Anthropology of education (Antropología de la Educación). The CIS-INAH had been founded in 1973 by three eminent figures: Gonzalo Aguirre Beltrán (1908-1996), Guillermo Bonfil Batalla (1935-1991) and Ángel Palerm Vich (1917-1980). This centre had the objective of endorsing studies and investigations of current issues in the country (including education).

De la Peña had been assigned by Palerm to direct another seminar about Anthropology of Education, that lasted from 1974 to 1978 . He invited the grantees of the seminar on the history of education to be part of this new project of investigation. Luz Elena Galván, along with Manola Sepúlveda and Patricia Greaves, incorporated to the project set in Casa Chata, in the municipality of Tlalpan. In that place she would come into contact with Beatriz Calvo, another grantee. In this manner, Galván started her career as an investigator within academia in 1974, a career that would last forty-five years (until 2019).

Here I worked in an interdisciplinary project with anthropologists, sociologists and historians. Each member of the group had their own task and their own subject. By then, I was finishing my bachelor degree in history, so I decided to turn my investigation there into my dissertation about José Vasconcelos and the creation of the SEP (Severetariat of Public Education) in 1921. Theoretically and methodologically, I was guided by positivism, since that had been the predominant perspective during my major. Even when I was part of an institution whose focus was anthropology, I always stood my ground as historian, and that is why that remained my standpoint.

When each of the grantees finished their investigation, the seminar was supposed to end too, but fortunately, Guillermo Bonfil (now general director) gave his authorization to keep that space opened for future investigations on the subject of education: "space that slowly grew with the addition of Mireya Lamoneda Huerta, Ma. Eugenia Vargas, Susan Street and María Bertely Busquets" (Calvo, 2019, s/p). It has to be mentioned that, by 1980, the CIS-INAH was restructured and became the Centre for Investigations and High Studies in Social Anthropology (CIESAS); Galván would also be part of this new institution. 
Even when she was determined to maintain her point of view according to her historical formation, Luz Elena Galván was not indifferent to new theories and methodologies. As she came into contact with innovative perspectives, she incorporated these in her own reflections upon education. Working with their colleagues every day, having academic (interdisciplinary) debates as well as advances in methodologies, were all elements that made Galván question her given view of the past, framing it instead in new structures. In addition, the historiographical variations that were happening globally are worthy of mention, because these forms of investigation that were surging in the seventies came to be "as a result of the influence of social sciences and a renovated historiography" (Meníndez, 2009, p. 152). In places like France, England, and later Italy and Spain, there was a new possibility rising that allowed researchers to undertake historical reconstructions that did not follow the traditional ways to write history. In this way, History passed from considering only the victorious, those above the common folk, to focus on those groups without history: the general population, especially minorities like women, children, teachers, schools, among others.

These historiographical proposals arrived in Mexico in the eighties, holding up in the nineties up to these days. Researchers of that time were ready to use these to get new approaches, reading and revising traditional bibliography. Luz Elena Galván was part of this effort to revise the old methodologies. She studied and analysed several authors like March Bloch, Lucien Febvre, Fernand Braudel, Jaques Le Goff and Marc Ferró, all of them French investigators that were part of the Annales School of historiography and that had been "her first encounter with the study of common people and everyday life" (Galván, 2014, p. 46).

Social history was a new field for her, and as she was permeating it, each project of which she was part also served to complement her. An example of this is her incursion in the study of indigenous education, in which she collaborated with Beatriz Calvo Pontón, Teresa Carbó, Víctor Franco and José Antonio Flores. This exploration would lead her to regional history.

Another account worth relaying is her decision to go beyond the bachelor's degree on history and take a further step in her academic training by getting a master's degree in her alma mater (Iberoamerican University). She presented her professional examination on October 22nd, 1982, receiving her degree (qualification) in next January. She finished her credits, presented a dissertation and defended it; her dissertation was directly related to her investigation in the CIESAS, and was about the education in indigenous groups of Mazahua people in Atlacomulco (in the State of Mexico).

She kept her academic improvement by entering a doctoral program in history in the same university (her alma mater). In her doctoral research, she focused even more in the social history of education, investigating the standpoint of the magisterium during the Porfiriato (Porfirio Diaz's rule). This dissertation represents a major contribution, not only because of the importance of the topic, but by her use of the primary sources she located in the Historical Archive (archivo histórico) "Francisco Xavier Clavigero". With this investigation, she was able to reconstruct the history of teachers, and to display to what extent they are in vulnerable situations.

Luce got her $\mathrm{PhD}$ in 1988 and, throughout her career, history would be the axis of her analyses. Her interest in this discipline was to recall part of history of people who had been vanished from it; her academic resolution was to bring them back and make them visible. With every new investigation, she had a new approach; any object she undertook (magisterium, indigenous people's education, informal instruction -related to ordinary life-, the study of childhood, women education, and so forth) had a new way to address it. Her sources also grew as she saw other possibilities beyond the usual documents, taking images, photographs, newspapers, school books and oral history as valid sources of information. This last is significant given that she not only embarked on the analysis of objects of study (or rather subjects) that had been basically overlooked, but she also stated the need for historians to look beyond our usual (and comfortable) methodologies/paradigms, to use all sources of information to look with a critical view and re-enact, through narrative, the most accurate representation of our past (as humans).

In the next section we relate some contributions made by Luz Elena Galván y Lafarga. As her work is extensive, we will only refer to the most emblematic pieces. The works we are talking about are those that -like her- have left an indelible mark in the history of education in Mexico. 


\subsection{Luz Elena Galván, education historian}

Undoubtedly, Luz Elena Galván has explored original topics. Her affinity with social history, the interdisciplinary subject she took up with her colleagues in the CIESAS, and the subsequent development of the regional and cultural history of education, made of her a figure that in Mexican academia is now recognized as eminence in this branch of history. She became known internationally too. She was able to create, lead and consolidate diverse team works, creating a network of academics in both national and international contexts. She trailblazed many topics for research that today are still taken up by a new generation of historians; many of the historiographical improvements that are published today in specialized magazines, that appear in book chapters and that are presented in conferences, reference her work.

The Professional career of Luz Elena Galván is broad. She has published more than a hundred peer reviewed articles and has authored over fifty books. In all of those publications, Dr. Galván was committed to her role as historian. Her keen interest in understanding the educational past of our country led her to wander, incessantly, over the progress of history; as she continued her research, she started pioneering on new topics and study objects that had been merely mentioned in other works.

It is important to question why Luz Elena Galván chose history of education as her preferred field of study, as well as to learn what motivated her decision to first take up education as her focal theme, and to know on what aspects, elements, and historical development of this theme she focused. In this respect, we can quote from Luce herself to speak for her own reasons:

On the question of why and for whom I write as a historian, I would like to say that, given the fact that I have worked for over 39 years around the history of education, my main interest is to make known to the faculty of today, the educational practice of yesterday. I wanted to show them how teachers were formed, how well they were trained, and how they became so qualified that they were able to author the same books that were being used in classrooms. I would like to transmit to this new generation how committed this guild was, how engaged in their teaching practices, and to the children they were educating, not only giving them knowledge, but providing ethical values that would someday be an inherent part of citizens [...] I write to the faculty of today, so they awaken (because they have been sleeping for decades). I write to tell them that they should not be part of the bureaucratic machine, just another gear turning, but they should be more than that on account of the duty they have to the education of children, for children are the most precious thing our country possesses. (Galván, 2014, pp. 50-51)

In this quote, we can see yearning, hope and desire to help the community of teachers, since she considers they should be the axis in which education pivots toward something better. For her, it is important to acknowledge the work of teachers, but they should also be made aware of the responsibility they carry in their practice. Taking into account the reason that led Galván to the history of education, we would like to refer two of her historiographical works that have become compulsory for education historians: the Dictionary of History of Education in Mexico (Diccionario de Historia de la Educación en México) and "Historiography of Education ("Historiografía de la Educación"). The first one can be found digitally in a CD published in 2000, while the second one is the volume ten of "The educational investigation in Mexico 1992-2002" (La investigación educativa en México), published by the COMIE (Mexican council for the investigation on education), in 2003.

The dynamic offered by the seminar, as a place to discuss freely, was favoured by Luz Elena Galván and their colleagues at the CIESAS. For them, the academic spaces used in this way made possible the sharing and commentary of their own investigations. In 1998 Galván, along with Beatriz Calvo, founded the Seminar of Educational Investigation, a space for reflection and analysis that included academics from several institutions who were interested in the subject of education. Hard work, constant debate, and the use of -then- new historiographical trends fostered new initiatives that brought novel investigations on the educational past. 
It is in this context that the Diccionario de la Historia de la Educación (Dictionary of History of Education), coordinated by Luz Elena Galván, emerges. She mentions that this work "has an antecedent in 1993, during the Second National Congress for Investigation on Education, when she was asked to create a state of knowledge on our country's [Mexico] historiography of education" (Galván, 2000, s/p). She accepted and the community of historians of education created the Comité para el Fomento y Desarrollo de la Historia de la Educación (Committee for the Development and Promotion of the History of Education) for that purpose and started operating the year after. Through this committee she proposed to make a historical project to give continuity to the investigative work that historians specialized in education were making: "we chose to present the project for the dictionary to the CONACYT, and it was wholly developed in two years (1999-2000)" (Galván, 2000, s/p).

We can see in the dictionary's introduction that the project was indeed interinstitutional. It gathered the collaboration of academics from twelve different institutions of higher education. The CD is conformed by sections: introduction, articles (thirty-two of them), glossary, biographies, annotated bibliography and photographs. Dr. Galván mentioned that the dictionary was structured as a reference book that could be used in a teacher training college:

... it will be easier than a book, that is usually expensive and too often is not accessible to teachers. Today, most colleges for teachers have computers, where the teachers in training can easily access this. (Galván, 2000, s/p)

With this quote we can reaffirm what we mentioned in previous paragraphs: the importance that Galván placed on teachers and their labour. For her, it was essential that teachers became aware of the variables in education (its history), so they could tackle not only pedagogical matters, but also elements from their context, in order to be able to analyse them and sort them out/act accordingly.

In this respect, we would like to mention that the articles mentioned here, that are part of a dictionary, are grouped in traditionally arranged historical periods: colonial, XIX and XX centuries. Each section includes several of our contributions, which reconstruct the history of a variety of objects of study, all of them resorting to different sources and reference books.

In sum, there are three elements that make of this dictionary an innovative piece: first, the themes, sources and archives that the authors consulted and used to write these articles, using photographs as another historical source that is able to safeguard the historical and educational memory; second, the digitality of the whole endeavour. The time in which it was published, showed that history of education in Mexico is a fertile field, that offers the possibility of a wide variety of studies; the objects are broad and each one of the contributions made by researchers are part of the immense structure of education.

The other work mentioned, "Historiografía de la Educación", also coordinated by Luz Elena Galván, along with Susana Quintanilla and Clara Inés González, is part of an editorial collection called La investigación educativa en México 1992-2002 (Educational Research in Mexico 1992-2002), and it was funded by the COMIE with a view to boost this type of investigation in the country. This council has organized (up to date) fifteen congresses (the first one in 1981) in which a diverse set of specialists in education (including in its history) have gathered. It was in the second congress that they came up with the idea of assessing the state of knowledge in this area.

In this work, the coordinators gathered a group of specialists that, together, gave an account of the state in which educational historiography was in the nineties and the beginning of the new millennium (2000s): "The objective of this state of knowledge was, precisely, to investigate the way in which the past has been written/recorded by education historians (Galván, 2003, p. 21). 
The state of knowledge covers the viceregal period (nineteenth and twentieth century). In this chronological fragment we can emphasize three main aspects: first, a thematical organization; second, the reach of the events that create "structures and processes, synchronicity and diachronicity, from very different natures. In fact, we are talking about a plural and multiform past” (Galván, 2003, p. 21). Finally, to acknowledge the interdisciplinary link that history of education has with pedagogy, anthropology, sociology and literature. This interdisciplinarity has risen new questions, what in turn has endorsed the diversification of referential sources. It is with these sources that we can recreate histories about "the knowledge, memories, practices, norms, forms of socialization and the material symbolic elements" (Galván, 2003, p. 22).

We would like to close this section by mentioning that Luz Elena Galván was part of the development, professionalization and consolidation of the history of education in Mexico. As a trailblazer in many research topics, she worked hard to reconstruct and understand different aspects of education, always keeping in mind the present in which history is anchored, even though she recognized that what we are today is the by-product of past events. What happens today must be explained from a historical perspective; learning the development of educational processes is a feature that we cannot elude, because only in this way can we achieve a betterment of teaching systems.

\subsection{Conclusion}

This work has been created by the conjoint effort of women researchers whose interest is to describe, from a polysemic and transdisciplinary view, the intellectual biographies of Latin-American women. This is done with a view to discover, visibilize and find meaning in the struggles, strategies, accomplishments and unresolved issues that conformed and sculpted their life projects, whose completion was centred around academic development.

We have chosen to approach our object of study from a theoretical and methodological point of view that uses social-cultural history, gender perspective and intellectual biography. From that point on, and thanks to the contribution of academics such as Luz Elena Galván, Marcela Santillán and Belinda Arteaga, as well as Peruvian Lucrecia Janqui, we were able to create a space in which these stories could be known. Thanks to these dream weavers, who built threads capable of resisting the constant probing of a patriarchal world (that tried to negate their involvement and even existence, making them invisible by placing them away from the public eye) is that we can embark on this project.

From gender relations that are marked by exclusion, inequality and violence towards women by the patriarchy, to the supposedly neutral context given by academia, these women fought, found allies and became stronger through their own silenced cooperation. This collusion allowed them to overcome obstacles in order to advance their projects. They managed to sign and edit their own work, to obtain funding to keep on working - even in expensive projects-, to produce and create cultural value that provided society with a new and critical vision on education and its history, and basically to trailblaze and shape a new generation of researchers.

One of the outcomes of this project, as we can already perceive, is the progress in the biographical writing of Luz Elena Galván y Lafarga's life. She is no longer with us, but remains close and dear to the project. We started writing her life story using diverse sources, such as recorded interviews, in which she explains when and why she opted ("was seduced") by History. She talks about details involving her family and early schooling that brought her into contact, and brewed a fascination, with this discipline. She also describes the many tears she shed when her father expressed -and thus decreed- a prohibition for his daughters to study; she likewise mentions the determination of her mother, that assisted this fascination and ended up opening the world for her.

The lines that are incomplete in this text serve both as a foreshadowing and a commitment on our part, since that is the reason for Aquelarre to exist: to reunite, during enjoyable evenings, and celebrate life and all the stories that surge from it.

\subsection{Acknowledgments}

Thanks to Diana Elizabeth García Arroyo for her translation support. 


\subsection{References}

Arteaga Böhrt, A. C. (2013). "Todas somos semilla" Ser mujer en la política comunitaria de Guerrero:ideologías de género, participación política y seguridad. México: Centro de Investigaciones y Estudios Superiores en Antropología Social. Retrieved from: http://repositorio.ciesas.edu.mx/bitstream/handle/123456789/232/M567.pdf?sequence=1\&isAllowed=y

Arteaga Castillo, B. (2016). "Los archivos históricos de las escuelas normales: Un parteaguas para la historia de la formación de los maestros mexicanos". En M. E. Aguirre Lora, Historia e historiografía de la educación en México. Hacia un balance 2002-2011. Vol. I. México: Consejo Mexicano de Investigación Educativa.

Berger, A. (2015). "Los fines de un idioma o la 'diferencia sexual'”. Revista Interdisciplinaria

Bloch, M. (2010). Introducción a la historia. México: Fondo de Cultura Económica.

Bruno, P. (2012). Biografía e historia, reflexiones y perspectivas. Anuario IEHS, (27), 113-119.

Burke, P. (1993). La revolución historiográfica francesa. México: Gedisa.

Calvo, B. (2019). "A mi querida Luce el día de su homenaje". Ichan Tecolotl, s/p. Retrieved from: https://tecolotl.ciesas.edu.mx/puntos-de-encuentro-anteriores/a-mi-querida-luce-el-dia-de-su-homenaje/

Canales, A. (2007). La política científica y tecnológica en México: el impulso contingente en el periodo 1982-2006. México: Facultad Latinoamericana de Ciencias Sociales.

COMIE. Consejo Mexicano de Investigación Educativa. Retrieved from: htp://www.comie.org.mx/v5/sitio/historia/

Delgado, G. (2008). Historia de México: legado histórico y pasado presente. México: Pearson.

Domenella Amadio, A. R. (2009). Autobiografía ficcionalizada en la narrativa de Maria Luisa Puga. Ciudad de México: Universidad Autónoma Metro. Retrieved from: http://tesiuami.izt.uam.mx/uam/aspuam/presentatesis.php?recno=15463\&docs=UAMI15463.pdf

Ducoing Watty, P. (2005). "En torno a las nociones de formación”. En P. Ducoing Watty, Sujetos, actores y procesos de formación (p. 833). México: Consejo Mexicano de Investigación Educativa. Retrieved from: http://www.comie.org.mx/doc/portal/publicaciones/ec2002/ec2002_v08_t2.pdf

Filinich, M. I. (10 de 07 de 2020). La perspectiva en la narración: una guía para la lectura. Retrieved from: https://www.uv.mx/cpue/coleccion/N_29/la_perspectiva_en_la_narraci\%C3\%B3n.htm

Galván, L. (2000). Diccionario de Historia de la Educación en México: México, Centro de Investigaciones y Estudios Superiores en Antropología Social, Universidad Nacional Autónoma de México, Consejo Mexicano de Ciencia y Tecnología. Retrieved from: http://biblioweb.tic.unam.mx/diccionario/htm/indart.htm.

Galván, L. (2014). "Cómo aprendí el 'oficio' para llegar a ser investigadora del CIESAS. 1974-2013". En L. Machuca (Comp.), Algunas historias sobre la historia contada por los investigadores del CIESAS (pp. 45-54). México: Centro de Investigaciones y Estudios Superiores en Antropología Social.

Galván, L. Quintanilla, S. y Ramírez, C. (2003). Historiografía de la educación en México. México: Consejo Mexicano de Investigación Educativa.

Gamiño Muñoz, R. (2013). Resistir al olvido. Iniciativas no oficiales de la memoria implementadas por ex militantes del movimiento armado socialista en la ciudad de México y en Guadalajara (2000-2011)". Centro de Investigaciones y Estudios Superiores en Antropología Social. Retrieved from: http://repositorio.ciesas.edu.mx/bitstream/handle/123456789/238/D237.pdf?sequence=1\&isAllowed=y 
García de León Álvarez, M. A. (2016). "Género, poder y conocimiento. Para una biografía intelectual desde las ciencias sociales y la perspectiva de género". Investigaciones feministas, 7(2). Recuperado de https://revistas.ucm.es/index.php/INFE/article/view/53780

Gómez, J. (2021). “¿Qué es una biografía intelectual? A propósito del caso de Rafael Gutiérrez Girardot” en Zuluaga Quintero, D. A y Quiroz Jiménez, L. F. (2021). Ensayos de historia intelectual. Inclusiones metodológicas. Colombia: FOCO/Fondo Editorial Facultad de Comunicaciones y Filología/Universidad de Antioquía, pp. 73-100.

Historia Abierta. (28 de julio de 2014). Haciendo historia de América Latina: Luz Elena Galván [Archivo de video]. Youtube. https://www.youtube.com/watch?v=vbRY20nxl3E\&t=27s

Hobsbawm, E. (2003). Años interesantes. Una vida en el siglo XX. Barcelona: Crítica. La educación superior en México y sus perspectivas. Coordinación nacional para la planeación de la educación superior. Recuperado de http://publicaciones.anuies.mx/acervo/revsup/res039/txt8.htm

Leñero, M. I. (2016). "La escuela en la literatura". En M. E. Aguirre Lora, Historia e historiografía de la educación en México. Hacia un balance 2002-2011. Vol II. (p. 391). Asociación Nacional de Universidades e Instituciones de Educación Superior, Consejo Mexicano de Investigación Educativa.

López Pérez, O. (2016). "Reflexiones sobre aportes y retos de la perspectiva de género en la historiografía de la educación en México". En M. E. Aguirre Lora, Historia e historiografía de la educación en México. Hacia un balance 2002-2011. Vol. II (p. 391). México: Consejo Mexicano de Investigación Educativa.

Martín Díaz, J. G. (2014). Experiencias de las asociaciones femeniles evangélicas en el sureste de México 1870-1960. Mérida Yucatán, México: Centro de Investigaciones y Estudios Superiores en Antropología Social. Retrieved from: http://repositorio.ciesas.edu.mx/bitstream/handle/123456789/288/D263.pdf?sequence=1\&isAllowed=y

Matabuena, T. (2018). "La Ibero: origen y desarrollo. Algunas notas sobre la historia de la Universidad Iberoamericana". Ibero. Revista de la Universidad Iberoamericana, (55), 27-32. Retrieved from: http://revistas.ibero.mx/ibero/uploads/volumenes/41/pdf/IBERO55_completa_final_(3)._CON_CORR ECCIONES_AL_19_de_abril_de_2018.pdf?_ga=2.173326755.1888882849.16170832311156717569.1617083231

Meníndez, R. (2009). "La historia de la educación en México: Nuevos enfoques y fuentes para la investigación". Sarmiento: Revista Galego-Poruguesa de Historia da Educación, (13), 151-164. Retrieved from: https://dialnet.unirioja.es/revista/1686/A/2009

Morales Vinicio, M. M. (2014). “Aquí la mujer se siente más responsable” Género y etnicidad Rarámuri en la Ciudad de Chihuahua. Entre relaciones de complementariedad y desigualdad. Centro de Investigaciones y Estudios Superiores en Antropología Social. Retrieved from: http://repositorio.ciesas.edu.mx/bitstream/handle/123456789/252/D248.pdf?sequence=1\&isAllowed=y

Moreno Olivos, T. y Gómez López, M. d. (2005). “Formación y Valores”. En P. Ducoing Watty, Sujetos, actores y procesos de formación (p. 833). México: Consejo Mexicano de Investigación Educativa. Retrieved from: http://www.comie.org.mx/doc/portal/publicaciones/ec2002/ec2002_v08_t2.pdf

Reyes Maza, M. d. (2013). Experiencias hacia la construcción de la reinserción. Historias de jóvenes que entre la desolación, la desesperanza, las carencias y las encrucijadas construyen camino. Xalapa Veracruz, México: Centro de Investigaciones y Estudios Superiores en Antropología Social. Retrieved from:

http://repositorio.ciesas.edu.mx/bitstream/handle/123456789/221/M566.pdf?sequence=1\&isAllowed=y

Sánchez Reyes, F. d. (2006). Totalmente desnuda. Biografía intelectual de Nahui Olin. México: Universidad Nacional Autónoma de México/Facultad de Filosofía y Letras/Instituto de Investigaciones Filológicas. Retrieved from: http://132.248.9.195/pd2007/0612569/Index.html 
Scott, J. (1990). "El género, una categoría útil para el análisis histórico", en: Amelang y Nash. Historia y género: las mujeres en la Europa moderna y contemporánea. España: Editorial Alfonso el Grande.

Scott, J. (1991). "Historia de las mujeres", en: Burke, P. Formas de hacer historia, Madrid: Alianza.

Serrano Castañeda, J. A. (1995). "Comprender la acción de formar a los profesores". En SEP-UPN, Formación docente, modernización educativa y globalización (pp. 211-218). México: Secretaría de Educación Pública/Universidad Pedagógica Nacional.

Torrentera, A. (s.f.). Mujeres transexuales y su reconocimiento legal en la Ciudad de México: Sistema sexo-género, subjetividad y biopoder. México: Centro de Investigaciones y Estudios Superiores en Antropología Social. Retrieved from: http://repositorio.ciesas.edu.mx/bitstream/handle/123456789/80/M486.pdf?sequence=1\&isAllowed=y

Torres, V. (1993). "Los educadores franceses y su impacto en la reproducción de una élite social" en J. Pérez y C. Cramaussel (Dirs.), México Francia: Memoria de una sensibilidad común; siglo XIX-XX. Tomo II (s/p). México: Centro de estudios mexicanos y centroamericanos.

Zamora García, J. (2014). Revisión histórica de la Guerrilla de Guadalajara: las fuerzas revolucionarias armadas del pueblo. México: Centro de Investigaciones y Estudios Superiores en Antropología Social. 